\title{
THE CORRELATION HABIT OF MIND MATHEMATICS AND MATHEMATICAL-PROBLEM SOLVING ABILITY ON THE SUBJECT TWO-DIMENSIONAL FIGURE
}

\author{
Nikmah Sidi Awaly ${ }^{1}$, Ade Triana ${ }^{2}$ \\ ${ }^{1,2}$ Student of Mathematics Education, IKIP Siliwangi, Cimahi, Indonesia \\ 1'-nikmahsa@gmail.com, 2adetrianadinata@gmail.com
}

Received: Jul 29 $9^{\text {th }}, 2019 ;$ Accepted: Sept $19^{\text {th }}, 2019$

\begin{abstract}
This research already existed before, but this research is different. The purpose of this study is to identify whether there is a positive correlation between habit of mind mathematics and mathematical problem solving abilities of students on the subject two-dimensional figure. This research is classified as quantitative correlational research. The population in this study were all seventh grade students at MTs. Negeri Sumedang 2016/2017 academic year. The sample is class VII D students with purposive sampling technique. The test instrument was a test of mathematical problem solving ability and a mathematical habit of mind attitude scale. The technical data analysis uses simple linear regression analysis. The results of this study are that there is a positive correlation between habit of mind mathematics and mathematical problem solving abilities for middle school students.
\end{abstract}

Keywords: Mathematical-Problem Solving Skill, Habit of Mind

\begin{abstract}
Abstrak
Penelitian ini sudah ada sebelumnya, namun penelitian ini berbeda. Tujuan penelitian ini untuk mengidentifikasi apakah ada korelasi positif antara habit of mind matematis dan kemampuan pemecahan masalah matematik siswa pada subjek bangun datar. Penelitian ini tergolong penelitian kuantitatif korelasional. Populasi dalam penelitian ini seluruh siswa kelas VII di MTs. Negeri Sumedang tahun akademik 2016/2017. Sampel adalah siswa kelas VII D dengan teknik Purposive Sampling. Instrumen tes berupa soal tes kemampuan pemecahan masalah matematik dan skala sikap habit of mind matematis. Teknis analisis data menggunakan analisis regresi linear sederhana. Hasil dari penelitian ini adalah terdapat korelasi positif antara habit of mind matematis dan kemampuan pemecahan masalah matematik siswa sekolah menengah.
\end{abstract}

Kata Kunci: Kemampuan Pemecahan Masalah Matematik, Kebiasaan Berpikir

How to Cite: Awaly, N. S. \& Triana, A. (2019). The Correlation Habit of Mind Mathematics and Mathematical-Problem Solving Ability on The Subject Two-Dimensional Figure. JIML, 2 (3), 104-111.

\section{INTRODUCTION}

Habit of mind is one of the important affective aspects for students (Ario, 2015; Masni, 2018; Miliyawati, 2016; Permendikbud, 2016). The use of habit of mind mathematically develops 
more on students' attitudes in gaining knowledge, for example students are able to survive and be responsible for the problems they receive so they are able to learn continuously.

The indicator of mathematical habit of mind is being able to survive in working on math problems, managing impulsively in thinking of answers before answering mathematical questions, listening with understanding and empathy by accurately describing, flexible thinking by utilizing a number of problem solving strategies, thinking metacognition by pondering and evaluating settlement plans, struggling for accuracy (right and correct), questioning and causing problems, applying past knowledge to new situations, thinking and communicating with clarity and precision in using mathematical language, collecting data through all senses, creating, imagining, innovating, responding with sense admiration, being able to be responsible for risk, finding humor (finishing relaxed and enjoying the problem category), thinking independently (working in groups), and staying open to continuous learning (Costa \& Kallick, 2008; Sumarmo, 2014). Based on these indicators, mathematical habit of mind has a role in shaping students 'mindsets which will have an impact on students' mathematical problem solving abilities in mathematics learning (Masni, 2018).

Mathematical problem solving ability is one of the cognitive aspects that must be possessed by each student (Abdullah, Mastur, \& Sutarto, 2015; Masri, Suyono, \& Deniyanti, 2018; Murniati, Mulyono, \& Kharis, 2017; Nurmarisa \& Mulyati, 2016; Permendikbud, 2016). This is because learning mathematics is not limited to reading or memorizing. More than that, students must be able to solve the problems they face. According to BNSP (Abdullah et al., 2015; Siswoyuono \& Susilo, 2016) in the standard guide to the content of mathematics subjects it was mentioned that problem solving focused on mathematics learning. Mathematical problem solving according to Polya (Aini, Purwanto, \& Sa'dijah, 2016; Noriza, Kartono, \& Sugianto, 2015) includes (1) understanding the problem, (2) arranging the plan, (3) implementing the plan, (4) checking again. In working on math problems we have actually used problem solving steps, but often we don't realize it. Not even a few students consider intelligent behavior in solving mathematical problems is difficult (Masni, 2018).

The results of the study by Mahmudi \& Sumarmo (2015) that learning with problem-based MHM strategies encourages students to think flexibly, such a way of thinking allows students to obtain various solutions or problem solving strategies. This is in line with the results of the study by Nurmarisa et. al. (2016) concluded the results of his research that the habit of mind mathematical strategy can improve mathematical problem solving abilities.

Therefore, it is necessary to do correlational analysis of habit of mind mathematics and mathematical problem solving abilities for students. The purpose of this study is to identify whether there is a correlation between habit of mind mathematics and mathematical problem solving abilities of students on the subject two dimensional figure? Meanwhile, the benefits of research are (1) through research, a description of the correlation between habit of mind mathematics and the mathematical problem solving abilities of students on the subject two dimensional figure is identified. (2) help the teacher in making learning plans on the subject two dimensional figure.

\section{METHOD}

The method used in this study is a quantitative method with a correlation approach. Free variable $(\mathrm{X})$ in this study is mathematical habit of mind, while the dependent variable $(\mathrm{Y})$ is the mathematical problem solving ability of students on the subject two dimensional figure. The population in this study were all seventh grade students at MTs. Negeri Sumedang 
106 Awaly \& Triana, The Correlation Habit of Mind Mathematics and MathematicalProblem Solving Ability on The Subject Two-Dimensional Figure

2016/2017 academic year. The sample was students of class VII D with a Purposive Sampling technique of 41 students. The test instrument was a test of mathematical problem solving ability and a mathematical habit of mind attitude scale that had been tested for validity and reliability. Examples of the scale of the habit of mind mathematical attitude are as follows:

\begin{tabular}{|c|c|}
\hline Sikap & Indikator \\
\hline $\begin{array}{l}\text { Ketika mengalami kesulitan dalam mengerjakan soal, sava terus } \\
\text { berusaha mencari solusi jawaban dan menyelesaikannya }\end{array}$ & 1 \\
\hline Saya menjawab pertanyaan guru tanpa memahami pertanyaannva & 2 \\
\hline $\begin{array}{l}\text { Dengan presentasi teman dan penjelasan dari guru membantu saya } \\
\text { dalam memahami materi dan mampu menyelesaikan soal pada materi } \\
\text { segiempat }\end{array}$ & 3 \\
\hline $\begin{array}{l}\text { Saya mampu mengerjakan soal menggunakan alternatif penyelesaian } \\
\text { lain }\end{array}$ & 4 \\
\hline $\begin{array}{l}\text { Ketika ada soal matematika, saya memperkirakan dahulu cara } \\
\text { pengerjaannya, baru kemudian mengerjakannya }\end{array}$ & 5 \\
\hline $\begin{array}{l}\text { Saya memeriksa setiap keteraturan langkah penyelesaian soal } \\
\text { matematika yang saya kerjakan }\end{array}$ & 6 \\
\hline Saya selalu bertanya ketika tidak mampu memahami materi & 7 \\
\hline $\begin{array}{l}\text { Saya mampu mengerjakan soal segiempat dengan bantuan rumus yang } \\
\text { telah dipelajari }\end{array}$ & 8 \\
\hline $\begin{array}{l}\text { Saya kurang mampu menggunakan simbol-simbol matematika dalam } \\
\text { mengerjakan soal matematika }\end{array}$ & 9 \\
\hline $\begin{array}{l}\text { Saya selalu menuliskan hal-hal penting tentang pelajaran di buku } \\
\text { catatan }\end{array}$ & 10 \\
\hline $\begin{array}{l}\text { Setelah menjawab suatu soal matematika, saya mempertanyakan } \\
\text { "apakah ada cara lain untuk menyelesaikannya"? }\end{array}$ & 11 \\
\hline Saya merasa senang setelah menyelesaikan soal matematika & 12 \\
\hline $\begin{array}{l}\text { Ketika nilai matematika saya jelek, sava akan terus rajin belajar agar } \\
\text { nilai saya menjadi lebih baik }\end{array}$ & 13 \\
\hline Saya tidak senang mengerjakan soal matematika yang sulit & 14 \\
\hline Sava kurang mampu menerima pendapat teman saat diskusi kelompok & 15 \\
\hline Sava tidak pernah mengulang kembali pelajaran matematika di rumah & 16 \\
\hline
\end{tabular}

Figure 1 Examples of Scale Mathematical Habit of Mind Attitudes

Tests of mathematical problem solving abilities have been tested for different strengths and the degree of difficulty of the questions. Test the mathematical problem solving abilities as follows:

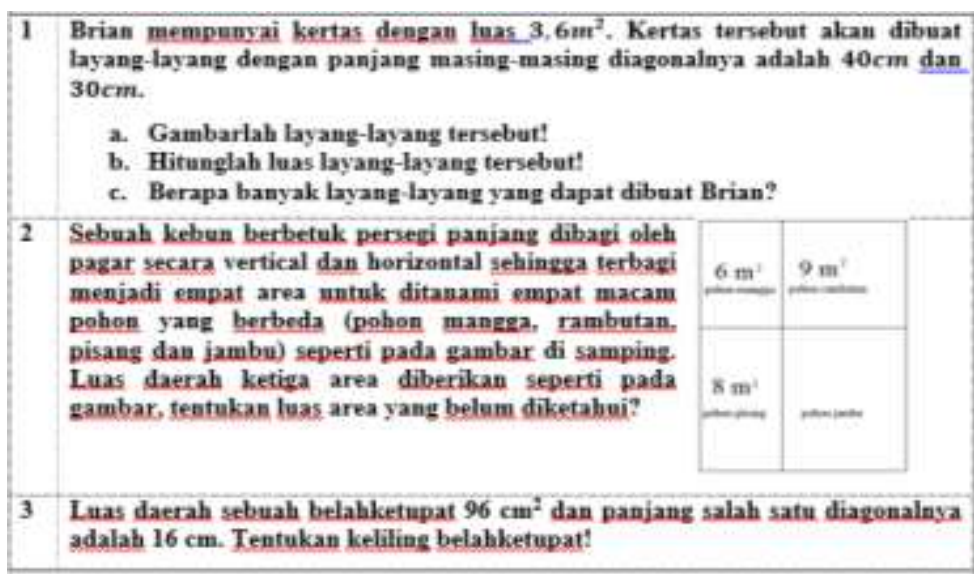

Figure 2 Mathematical Problem Solving Ability Test

The data analysis used in this study is simple linear regression, including (1) normality test, (2) regression equation, (3) linearity test, (4) significant regression test, (5) significant regression coefficient test, (6) test significant correlation coefficient, (7) coefficient of determination. 


\section{RESULTS AND DISCUSSION}

\section{Results}

The results of the previous normality test, data are normally distributed. Meanwhile, a simple linear regression calculation produces a regression equation $\mathrm{Y}=-45.465+1.383 \mathrm{X}$ regression indicating that there is an increase in students' mathematical problem solving abilities 1.383 for each unit of increased habit of mind mathematics.

Tabel 1 The Result of Linear Test

\begin{tabular}{|c|c|c|c|c|c|c|c|}
\hline & & & $\begin{array}{l}\text { Sum of } \\
\text { Squares }\end{array}$ & If & $\begin{array}{l}\text { Mean } \\
\text { Square }\end{array}$ & $\mathrm{F}$ & Sig. \\
\hline \multirow{5}{*}{$\begin{array}{l}\text { Mathematical- } \\
\text { Problem Solving } \\
\text { Ability * Habit } \\
\text { of Mind } \\
\text { Mathematics }\end{array}$} & \multirow{3}{*}{$\begin{array}{l}\text { Between } \\
\text { Groups }\end{array}$} & (Combined) & 2099.983 & 14 & 149.999 & .853 & .612 \\
\hline & & Linearity & 1242.066 & 1 & 1242.066 & 7.066 & .013 \\
\hline & & $\begin{array}{l}\text { Deviation from } \\
\text { Linearity }\end{array}$ & 857.918 & 13 & 65.994 & .375 & .966 \\
\hline & \multicolumn{2}{|c|}{ Within Groups } & 4570.186 & 26 & 175.776 & & \\
\hline & \multicolumn{2}{|l|}{ Total } & 6670.170 & 40 & & & \\
\hline
\end{tabular}

Based on the data in Table 1, the conclusion is that the correlation between habit of mind mathematics and mathematical problem solving abilities on the subject two dimensional figure is linear.

The results of the regression significance test are presented in Table 2.

Tabel 2 The results of the regression significance

\begin{tabular}{lllrrrr}
\multirow{2}{*}{ Model } & & $\begin{array}{c}\text { Sum of } \\
\text { Squares }\end{array}$ & Df & \multicolumn{1}{c}{$\begin{array}{c}\text { Mean } \\
\text { Square }\end{array}$} & F & Sig. \\
\hline \multirow{3}{*}{1} & Regression & 1242.066 & 1 & 1242.066 & 8.924 & $.005^{\mathrm{b}}$ \\
\cline { 2 - 7 } & Residual & 5428.104 & 39 & 139.182 & & \\
\cline { 2 - 7 } & Total & 6670.170 & 40 & & & \\
\hline
\end{tabular}

a. Dependent Variable: Mathematical-Problem Solving Ability

b. Predictors: (Constant), Habit of Mind Mathematics

Based on the data in Table 2, the conclusion is the correlation between habit of mind mathematics and mathematical problem solving abilities on the subject two dimensional figure with a significant.

The results of the significance test of the regression coefficient use the value of $t$ obtained that the regression coefficient is significant.

Tabel 3 The Result of the Degree of Corelation

\begin{tabular}{|c|c|c|c|c|c|c|c|c|c|}
\hline \multirow[t]{4}{*}{ Model } & \multirow[t]{4}{*}{$\mathrm{R}$} & \multirow{4}{*}{$\begin{array}{c}\mathrm{R} \\
\text { Square }\end{array}$} & \multirow{4}{*}{$\begin{array}{l}\text { Adjusted } \\
\text { R Square }\end{array}$} & \multirow{4}{*}{$\begin{array}{c}\text { Std. } \\
\text { Error of } \\
\text { the } \\
\text { Estimate }\end{array}$} & \multicolumn{4}{|c|}{ Change Statistics } & \multirow[t]{4}{*}{ Durbin-Watson } \\
\hline & & & & & $\mathrm{R}$ & $\mathrm{F}$ & df1 df2 & Sig. F & \\
\hline & & & & & Square & Change & & Change & \\
\hline & & & & & Change & & & & \\
\hline 1 & $.432^{\circ}$ & .186 & .165 & 11.79755 & .186 & 8.924 & 39 & .005 & 1.972 \\
\hline
\end{tabular}

a. Predictors: (Constant), Habit of Mind Mathematics

b. Dependent Variable: Mathematical Problem Solving Ability

Based on Table 3 the calculation of determination coefficient, the value of $r^{2}=0.186$ or $18.6 \%$. That is, the mathematical problem solving ability is influenced by $18.6 \%$ of the 
108 Awaly \& Triana, The Correlation Habit of Mind Mathematics and MathematicalProblem Solving Ability on The Subject Two-Dimensional Figure

mathematical habit of mind of students and $81.4 \%$ is influenced by other factors besides mathematical habit of mind.

Based on the calculation of the correlation coefficient obtained by the value $r=0.432$. According to Guilford criteria, 0.432 is included in the criteria for moderate correlation coefficient.

\section{Discussion}

Based on the analysis of research data it can be concluded that there is a positive correlation between habit of mind mathematics with mathematical problem solving abilities of students on the subject two dimensional figure. This is in accordance with the opinion of Nurmarisa et al. (2016) said that the application of thinking habits of mind to make students begin to get used to high-level thinking starting from solving routine problems to solving non-routine problems.

The truth of the hypothesis is supported by several related studies. Masni (2018) revealed that there was an association between mathematical problem solving abilities and the habits of mind mathematics of students who obtained Advanced Organizer Metacognitive Learning and students who obtained the Scientific Discovery Learning Approach.

This study uses a QSH learning model with 6 learning activities. The activities are (1) giving question cards; (2) write questions for each group; (3) playing cards throughout the group; (4) reviewing questions held; (5) make an agreement on the questions to be resolved and (6) resolve the questions. Analysis of student answers:

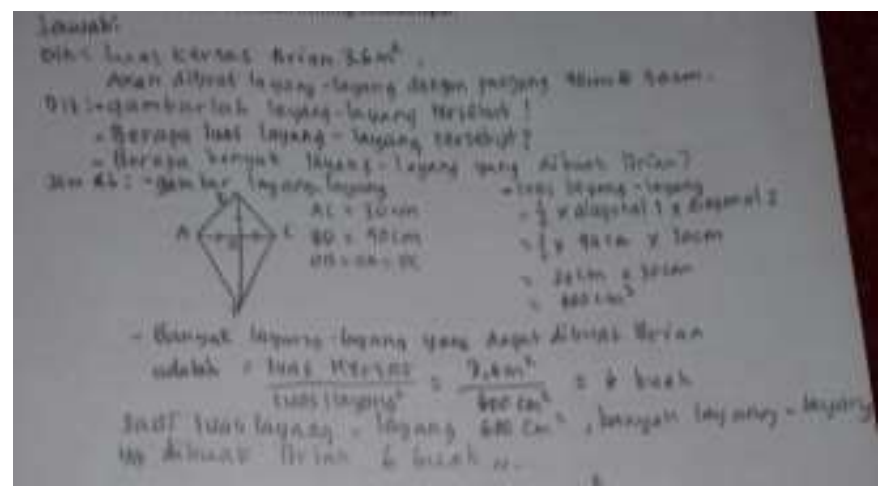

Figure 3 Student Answer No. 1

Based on Figure 3, student answers have referred to the steps for solving problems according to Polya. However, students do not make mathematical models correctly. Grade VII students have studied algebra and PLSV, students should be able to make mathematical models of the questions given by using language and mathematical symbols. 


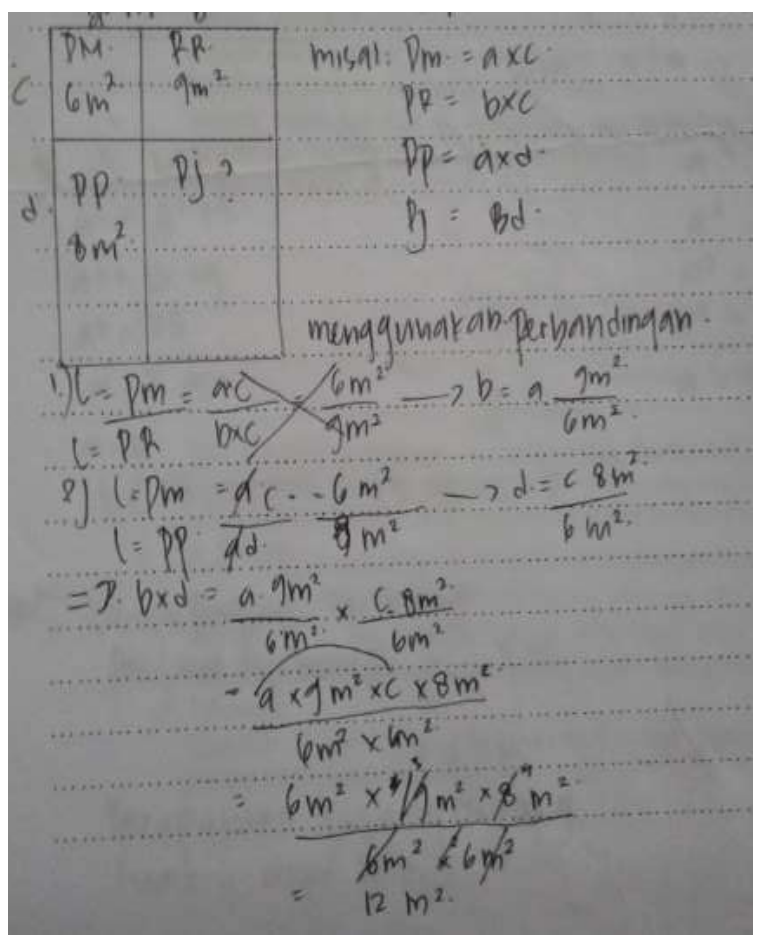

Figure 4 Student Answer No. 2

Based on Figure 4, students' answers are less precise. He did not write down the elements that were known, asked and adequacy of the elements, and did not reinterpret the results into the questions. As a result, student answers are less than perfect. But students are able to solve mathematical problems significantly, namely by using comparisons.

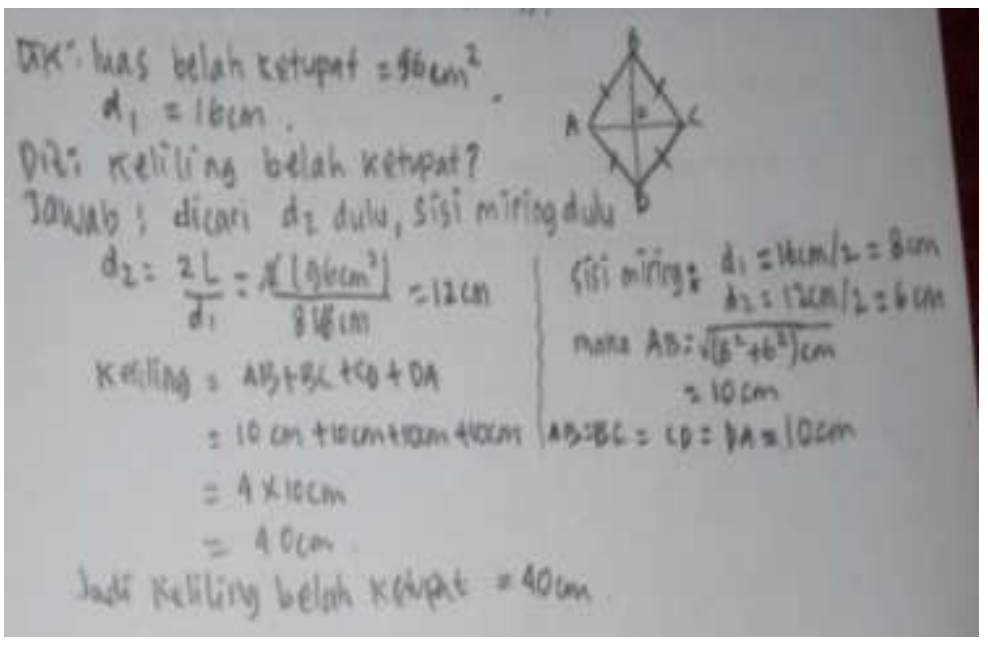

Figure 5 Student Answers No. 3

Based on Figure 5, students are almost perfect in using problem solving steps according to Polya. Students are able to solve mathematical problems significantly, using the Pythagoras formula.

\section{CONCLUSION}

The conclusion that can be drawn is that habit of mind mathematics has a significant correlation to the mathematical problem solving ability on the subject two dimensional figure for class VII students in MTs. Negeri Sumedang. This can be seen from the value of the habit 
110 Awaly \& Triana, The Correlation Habit of Mind Mathematics and MathematicalProblem Solving Ability on The Subject Two-Dimensional Figure

of mind mathematical questionnaire with the posttest value of students' mathematical problem solving abilities.

\section{REFFERENCES}

Abdullah, D. I., Mastur, Z., \& Sutarto, H. (2015). Keefektifan Model Pembelajaran Problem Based Learning Bernuansa Etnomatematika Terhadap Kemampuan Pemecahan Masalah Siswa Kelas Viii. Unnes Journal of Mathematics Education., 4(3), 285-291. https://doi.org/10.15294/ujme.v4i3.9056

Aini, K. N., Purwanto, \& Sa'dijah, C. (2016). Proses Koneksi Matematika Siswa Berkemampuan Tinggi dan Rendah Dalam Memecahkan Masalah Bangun Datar. Jurnal Pendidikan: Teori, Penelitian, Dan Pengembangan, 1(3), 377-388. https://doi.org/10.17977/jp.v1i3.6164

Ario, M. (2015). Penalaran Matematis dan Mathematical Habits of Mind melalui Pembelajaran Berbasis Masalah Penemuan Terbimbing. Jurnal Ilmu Pendidikan Dan Pengajaran, 2(1), 34-46.

Costa, A. L., \& Kallick, B. (2008). Learning and Leading with Habits of Mind 16 Essential Characteristics for Succes. Amerika: Association for Supervision and Curriculum Development.

Mahmudi, A., \& Sumarmo, U. (2015). Pengaruh Strategi Mathematical Habits of Mind (Mhm) Berbasis Masalah terhadap Kreativitas Siswa. Jurnal Cakrawala Pendidikan, (2), 216-229. https://doi.org/10.21831/cp.v0i2.4229

Masni, E. D. (2018). Pendekatan Pembelajaran Metakognitif Advance Organizer dan Scientific Discovery untuk Meningkatkan Kemampuan Pemecahan Masalah Matematika dan Kebiasaan Berpikir Matematis Siswa Kelas VIII. Jurnal Penelitian Matematika Dan Pendidikan Matematika, 1(1), 62-77.

Masri, M. F., Suyono, S., \& Deniyanti, P. (2018). Pengaruh Metode Pembelajaran Berbasis Masalah terhadap Self-Efficacy dan Kemampuan Pemecahan Masalah Matematis Ditinjau dari Kemampuan Awal Matematika Siswa SMA. Jurnal Penelitian Dan Pembelajaran Matematika, 11(1), 116-126. https://doi.org/10.30870/jppm.v11i1.2990

Miliyawati, B. (2016). Urgensi Strategi Disposition Habits of Mind Matematis. Infinity Journal, 3(2), 174. https://doi.org/10.22460/infinity.v3i2.62

Murniati, S., Mulyono, \& Kharis, M. (2017). PBL Learning using Working Backward Strategies to Improve Mathematical Problem Solving Ability. Unnes Journal of Mathematics Education, 6(1), 27-36. https://doi.org/10.15294/ujme.v6i1.10983

Noriza, M., Kartono, \& Sugianto. (2015). Kemampuan Pemecahan Masalah dan Disposisi Matematis Siswa Kelas X pada Pembelajaran Berbasis Masalah. Unnes Journal of Research Mathematics Education, 4(2), 66-75.

Nurmarisa, N. I., \& Mulyati, T. (2016). Kemampuan Pemecahan Masalah Matematis Siswa yang Mendapatkan Pembelajaran dengan Strategi Mathematical Habits of Mind Berbasis 
Masalah. Antopologi UPI, 1-14.

Permendikbud. (2016, April). Salinan Lampiran Peraturan Menteri Pendidikan dan Kebudayaan Nomor 20 Tahun 2016. https://doi.org/10.5151/cidi2017-060

Siswoyuono, A. M., \& Susilo, B. E. (2016). Komparasi Pembelajaran SAVI dan REACT pada Kemampuan Pemecahan Masalah Siswa Kelas-VIII Materi Kubus dan Balok. Beta Jurnal Tadris Matematika, 9(1), 15-33. https://doi.org/10.20414/betajtm.v9i1.3

Sumarmo, U. (2014). Handout Mata Kuliah Evaluasi Pembelajaran Matematika. 